\title{
Are we facing a post-antibiotic future in surgery?
}

\author{
H. Cerwenka $\cdot$ R. Krause
}

Published online: 11 April 2014

(C) Springer-Verlag Wien 2014

Propheten dieser Art verhöhnen die Zukunft, indem sie ihr sagen, wie sie sich gestalten werde, damit sie sich schäme, sich wirklich so zu gestalten (Prophets of this kind mock the future by telling it how it is going to emerge, in order to make it ashamed of really emerging in that way). [Thomas Mann, Der Zauberberg]

This editorial is intended to support the article by Loughran and Harrison published in this issue.

\section{Dear readers,}

The rapid developments in surgery in the past two centuries were, apart from the great success in surgical technique itself, fostered by the achievements of anesthesia, asepsis, and antibiotic therapy. However, one of these fundamental columns, antibiotic therapy, seems to be at risk [1]. Are we, the surgeons, to blame for causing this risk to our patients and to ourselves? Due to abundant use of antibiotics, growing resistance [2], and limited development of new substances, the threat of a "post-antibiotic era" may become real [3].

In this context, this editorial aims to address two main issues: first, are antibiotics overused in visceral surgery and where could their administration be restricted; and second, are there back-up strategies, are there new antibiotics in stand-by and in the pipeline, or are we really running out of effective antibiotic regimens in the near future? (Figs. 1 and 2)

Prof. Dr. H. Cerwenka $(\bowtie)$

Department of Surgery, Medical University of Graz,

Auenbruggerplatz 29, $8036 \mathrm{Graz}$, Austria

e-mail: herwig.cerwenka@medunigraz.at

Prof. Dr. R. Krause

Section of Infectious Diseases and Tropical Medicine, Department of Internal Medicine, Medical University of Graz,

Graz, Austria

\section{Overuse of antibiotics}

A wide field for potential overuse of antibiotics is prophylactic administration $[4,5]$. For many elective routine operations without inflammatory processes, antibiotic "coverage" will be necessary only in selected patients (immune suppression, implantation of foreign material, patients with valvular heart disease [6], etc.). If prophylactic use is considered appropriate for prevention of wound infection, in most of the patients, a single-shot dose will be sufficient $[5,7]$. The practice of giving antibiotics for 3 days as a routine prophylaxis, for example, after inguinal mesh graft hernioplasty, is not up to date [7]. Single-dose applications harbor less risk of development of resistance and of side effects. Detailed guidelines for antimicrobial prophylaxis, discussed separately for several kinds of surgical procedures, were recently published [7] and provide useful support in everyday routine, although they are based on limited data that are not always conclusive [8] and cannot replace clinical judgment.

In terms of therapeutic use, the potential for restriction seems to be lower at the first glance. Here the decisions are generally based on microbiology and sensitivity testing (for example, the spectrum of agents causing liver abscesses shows great variety both locally [9] and globally [10]) as well as on consultations with clinical microbiologists or infectious disease consultants. Notwithstanding the life-saving necessity of antibiotic therapy in sepsis and intensive care medicine, there is, however, a potential for reduction in the time span of administration. For instance, in patients with peritonitis and continuous negative pressure (CNP)/vacuum-assisted closure (VAC) treatment, antibiotics are often only necessary for a limited period, although it sometimes evokes surprise when there are no antibiotics on the charts of surgical intensive care patients even though their peritoneal cavity is not yet completely "clean" and their abdomen is not yet definitely closed. 


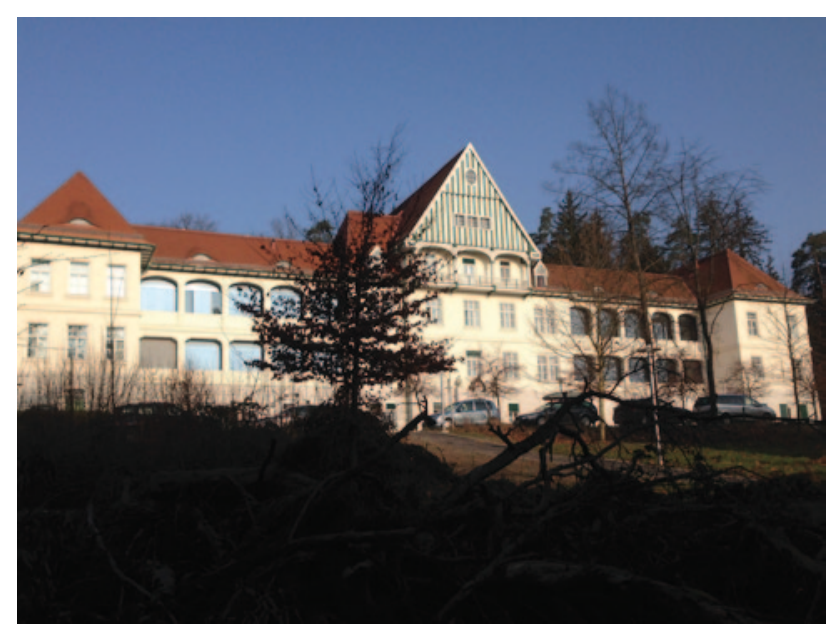

Fig. 1 A reminiscence of the pre-antibiotic era: the former Rekheim in Graz was a sanatorium for lung patients ("coughing castle") like Thomas Mann's Zauberberg. ("The Magic Mountain," published in 1924 and inspired by Prof. Jessen's Waldsanatorium in Davos)

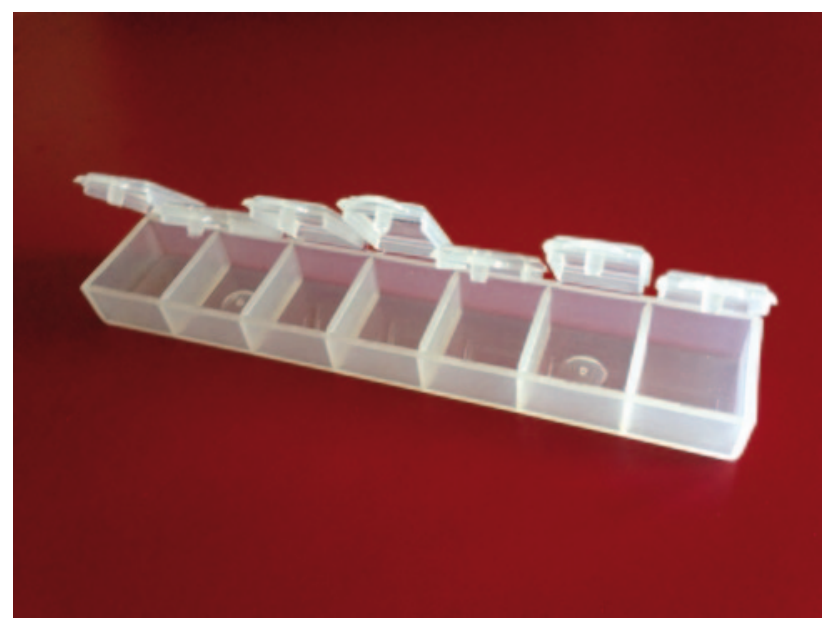

Fig. 2 Is our "pill box" going to be empty? Are we running out of effective weapons against the infective armada?

\section{Bad bugs, no drugs?}

Methicillin-resistant Staphylococcus aureus (MRSA) is still the best known of the problematic germs; however, there are many others that have developed multipledrug resistance. Especially for Gram-negative agents like Pseudomonas, Klebsiella, Neisseria, and Escherichia coli, the situation is becoming increasingly serious.

Meanwhile, more than a thousand different forms of the enzyme beta-lactamase, which opens the betalactam ring of antibiotics and thus makes them ineffective, have been described. Gram-negative agents with extended-spectrum beta-lactamases and Klebsiella pneumoniae carbapenemases represent a special danger. The presently used beta-lactamase inhibitors clavulanic acid, sulbactam, and tazobactam are able to cope with, for instance, penicillinases, whereas some other forms of
Table 1 List of common abbreviations

\begin{tabular}{|c|c|}
\hline MRSA & Methicillin-resistant Staphylococcus aureus \\
\hline MRSE & Methicillin-resistant Staphylococcus epidermidis \\
\hline VRE & Vancomycin-resistant enterococci \\
\hline VRSA & Vancomycin-resistant $S$. aureus \\
\hline ESKAPE & $\begin{array}{l}\text { Enterococcus faecium, S. aureus, Klebsiella pneumoniae, } \\
\text { Acinetobacter baumannii, Pseudomonas aeruginosa, } \\
\text { Enterobacter sp. }\end{array}$ \\
\hline ESCAPE [11] & $\begin{array}{l}\text { E. faecium, } S \text {. aureus, Clostridium difficile, A. baumannii, } \\
\text { P. aeruginosa, Enterobacteriaceae }\end{array}$ \\
\hline CRE & Carbapenem-resistant enterobacteria \\
\hline ESBL & Extended-spectrum beta-lactamase \\
\hline KPC & K. pneumoniae carbapenemase \\
\hline ABS & Antibiotic stewardship \\
\hline
\end{tabular}

beta-lactamases (like metallo-beta-lactamases) are not effectively inhibited.

In the past decade, the oxazolidinone linezolid became an antibiotic "blockbuster." It inhibits protein biosynthesis by binding to the 23S-rRNA of the 50S subunit of bacterial ribosomes and is well effective against many multiresistant Gram-positive agents (like MRSA, MRSE, VRE, and VRSA; see list of abbreviations, Table 1); however, Gram-negative bacteria have efflux pumps that actively transport it out of the bacterial cell, so linezolid is ineffective against them. A critical mechanism of developing resistance in Gram-positive organisms is the expression of chloramphenicol/florfenicol resistance (cfr) methyltransferase, which leads to the methylation of adenosine-2503 and thus prevents binding of linezolid. As the gene for this methyltransferase is localized on plasmids, it can spread very quickly, thus making the excessive use of linezolid potentially dangerous.

\section{A short glance at future developments}

While the main goal should be to preserve the effectiveness of the prevailing antibiotic regimens by using them in a rational way, it seems, nevertheless, justified in this context to take a brief glance at new substances tagged as "back-up," "stand-by," or "in the pipeline." Are we really running out of future antibiotic strategies?

In general, the antibiotics that are presently in the pipeline are further developments of already known substance classes, and the result of their clinical evaluations is still uncertain. Only a few of them are effective against multiresistant problematic germs of the Gram-negative spectrum (ESKAPE/ESCAPE pathogens [11]).

The new beta-lactamase inhibitor avibactam is the first substance of its group without beta-lactam ring and does not bind irreversibly to the enzyme (like, for example, clavulanic acid), so less molecules are required for inhibition.

New oxazolidinones include radezolid and torezolid (in phase III of clinical evaluation); they have a bacteriostatic effect on MRSA and enterococci and a bactericidal effect on Streptococcus pneumoniae and Haemophilus influenzae. 
New quinolones comprise delafloxacin, finafloxacin, and nemonoxacin. Delafloxacin has also been nicknamed "rambofloxacin"; a potential problem, however, may be photosensitization, which is known from previous substances of this halogen-substituted group of quinolones.

The glycylcycline tigecycline is a back-up antibiotic active against Gram-positive and Gram-negative germs, including many multiresistant microorganisms, as it is not a substrate for the bacterial tet-efflux pump; however, Pseudomonas and Proteus sp. are not susceptible to tigecycline.

Recently, problems with carbapenem-resistant enterobacteria have led to a renaissance of colistin, which has already been known for more than 50 years.

New cephalosporins include ceftaroline fosamil, which is already in use, as well as ceftobiprole medocaril and ceftozolane in the pipeline. Combinations of ceftozolane with tazobactam and ceftaroline with avibactam are presently evaluated.

Further examples for antibiotics in the pipeline are the aminoglycoside plazomicin, the ketolide solithromycin, and the tetracyclines omadacycline and eravacycline; however, they are still in phase II of clinical evaluation.

\section{Can a post-antibiotic era be prevented?}

Almost all the presently used antibiotics derive from Streptomyces species. While resistances developed by bacteria are on the rise, the number of big pharmaceutical companies active in research on new antibiotics has decreased. Enhanced research efforts will be required, also with public financing and private-public partnerships. So far, clinical studies generally require new substances to be superior to the antibiotics already in use. However, we are also going to need more substances with similar effectiveness, as the development of resistances is not predictable [12].

Rational application is the main key to success, including constant evaluation of antibiotic use and reduction as well as continuing education on this subject. The time provided for effective education in our discipline is only a fraction of what would be required $[13,14]$, and this particularly pertains to education on antibiotic usage. In a generally "technology, pharma- and food-industry driven" [15] environment, we get targeted by marketing interests and subjective information.

Of course, restricted use also involves the fields of veterinary medicine and plant protection. International, national, and local measures of quality control (in terms of selection, dosage, application, and time span) for antibiotic treatment ("antibiotic stewardship", ABS) are important as well as roundtables on antibiotic resistance, including delegates from research, administration, politics, and industry.

Finally, two quotations in lieu of a conclusion: Pour ce qui est de l'avenir, il ne s'agit pas de le prévoir, mais de le rendre possible (As for the future, our task is not to foresee it, but to enable it) [Antoine de Saint-Exupéry, Citadelle] and The best thing about the future is that it comes only one day at a time [Abraham Lincoln (attributed)].

\section{Conflict of interest}

The authors declare that there is no conflict of interest.

\section{References}

1. Loughran D, Harrison J. Antibiotic resistance: a long term, serious problem...getting worse. Thoughts on the future of surgery in a post-antibiotic era. Eur Surg. 2014.

2. Bassetti M, Righi E. Multidrug-resistant bacteria: what is the threat? Hematology Am Soc Hematol Educ Program. 2013;2013:428-32.

3. Alanis AJ. Resistance to antibiotics: are we in the post-antibiotic era? Arch Med Res. 2005;36:697-705.

4. Nelson DW, Champagne BJ, Rivadeneira DE, Davis BR, Maykel JA, Ross HM, Johnson EK, Steele SR. Prophylactic antibiotics for hemorrhoidectomy: are they really needed? Dis Colon Rectum. 2014;57:365-9.

5. Bassetti M, Righi E, Astilean A, Corcione S, Petrolo A, Farina EC, De Rosa FG. Antimicrobial prophylaxis in minor and major surgery. Minerva Anestesiol. 2014 Feb 24. Epub ahead of print.

6. Nishimura RA, Otto CM, Bonow RO, Carabello BA, Erwin JP 3rd, Guyton RA, O'Gara PT, Ruiz CE, Skubas NJ, Sorajja P, Sundt TM 3rd, Thomas JD. 2014 AHA/ACC Guideline for the management of patients with valvular heart disease: executive summary: a report of the American College of Cardiology/American Heart Association Task Force on Practice Guidelines. J Am Coll Cardiol. 2014 Mar 3. Epub ahead of print.

7. Bratzler DW, Dellinger EP, Olsen KM, Perl TM, Auwaerter PG, Bolon MK, Fish DN, Napolitano LM, Sawyer RG, Slain D, Steinberg JP, Weinstein RA; American Society of Health-System Pharmacists; Infectious Disease Society of America; Surgical Infection Society; Society for Healthcare Epidemiology of America. Clinical practice guidelines for antimicrobial prophylaxis in surgery. Am J Health Syst Pharm. 2013;70:195-283.

8. Gurusamy KS, Koti R, Toon CD, Wilson P, Davidson BR. Antibiotic therapy for the treatment of methicillin-resistant Staphylococcus aureus (MRSA) in non surgical wounds. Cochrane Database Syst Rev. 2013;11:CD010427.

9. Cerwenka H, Bacher H, Werkgartner G, El-Shabrawi A, Kornprat P, Bernhardt GA, Mischinger HJ. Treatment of patients with pyogenic liver abscess. Chemotherapy. 2005;51:366-9.

10. Cerwenka H. Pyogenic liver abscess: differences in etiology and treatment in Southeast Asia and Central Europe. World J Gastroenterol. 2010;16:2458-62.

11. Peterson LR. Bad bugs, no drugs: no escape revisited. Cin Infect Dis. 2009;49:992.

12. Holzgrabe U. Antibiotika-Neue Wirkstoffe in der Pipeline. Pharm Ztg online. 2012;20. www.pharmazeutische-zeitung.de. Accessed 27 Feb 2014.

13. Riegler FM. General surgery with qualities: sub the speciality. Eur Surg. 2013;45:1-2.

14. Cerwenka H, Bacher H, Werkgartner G, Mischinger HJ. Working conditions and trainee shortage in operative disciplines-is our profession ready for the next decade? Langenbecks Arch Surg. 2009;394:179-83.

15. Riegler FM. Surgery spring sounds: topic justifies. Eur Surg. 2013;45:45-8. 